\title{
PENGEMBANGAN USAHA KECIL DAN MENENGAH KELOMPOK MAKANAN, MINUMAN DAN TEMBAKAU DI KOTA TARAKAN
}

\section{(THE DEVELOPMENT OF MEDIUM AND SMALL BUSINESSES OF CIGARETTE, DRINK, AND FOOD GROUP IN TARAKAN CITY)}

\author{
Karmini*, Karyati** $^{* *}$ \\ *Fakultas Pertanian, Universitas Mulawarman. \\ Kampus Gunung Kelua, Jl. Pasir Balengkong, Samarinda, Kalimantan Timur, Indonesia.75123. \\ Email: karmini.kasiman@yahoo.com. \\ *** Fakultas Kehutanan, Universitas Mulawarman. \\ Kampus Gunung Kelua, Jl. Ki Hajar Dewantara, Samarinda, Kalimantan Timur, Indonesia, 75123. \\ Email: karyati.hanapi@yahoo.com.
}

Diterima: 1 Januari 2020; Direvisi: 14 Juni 2020; Disetujui: 17 Juni 2020

\begin{abstract}
ABSTRAK
Peningkatan jumlah Usaha Kecil dan Menengah (UKM) perlu terus dilakukan, di samping peningkatan upaya untuk mengembangkan usaha yang telah berjalan. Tujuan penelitian ini adalah untuk mengidentifikasi faktor-faktor internal dan eksternal, menentukan strategi serta menyusun program dan kegiatan pengembangan UKM kelompok makanan, minuman, dan tembakau. Penelitian dilaksanakan di Kota Tarakan, Provinsi Kalimantan Timur, Indonesia pada bulan Januari hingga Juni 2018. Penelitian ini mengumpulkan data primer dan sekunder dengan jumlah sampel sebanyak 21 responden. Data dianalisis dengan menggunakan analisis Strengths, Weakness, Opportunities, and Threats (SWOT). Hasil penelitian menunjukkan bahwa faktor-faktor internal dan eksternal yang mempengaruhi pengembangan UKM antara lain motivasi, bahan baku, tenaga kerja, modal, keuangan, teknologi, pemasaran, iklim usaha, dan pembinaan. Strategi pengembangan UKM dalam kelompok makanan, minuman, dan tembakau di Kota Tarakan adalah agresif. Programprogram pengembangan UKM antara lain program identifikasi dan pengembangan potensi daerah, program penguatan kemampuan ekonomi UKM, dan program peningkatan jumlah wirausahawan muda. Program tersebut dijabarkan dalam berbagai kegiatan pokok.
\end{abstract}

Kata kunci: UKM, faktor internal, faktor eksternal, strategi usaha, dan program pengembangan.

\begin{abstract}
The increasing quantity Medium and Small Businesses (MSB) is needed to be done as well as the increasing efforts to develop the existing MSB. The aims of this study were to identify the internal and external factors, to determine strategy also to arrange the programs and activities to develop the MSB of cigarette, drink, and food group. The study was done in Tarakan City, East Kalimantan Province, Indonesia since January to June 2018. This study collected primary dan secondary data with total sample as many as 21 respondents. Data were analyzed by using the analysis Strengths, Weakness, Opportunities, and Threats (SWOT). The results of this study show internal and external factors affect the development of MSB such as motivation, raw material, labor, capital, finance, teknologi, marketing, business climate, and assistance. The strategy to develop MSB in cigarette, drink, and food group is aggresive. Programs develop MSB such as identification and development of regional potency, strengthening of MSB economic ability, and increasing of young entreprenuers. Those programs are derived become some importants activities.
\end{abstract}


Keywords: SME, internal factor, external factor, bussines strategy, and development program

\section{PENDAHULUAN}

Perekonomian nasional ditopang oleh pergerakan berbagai usaha diantaranya Usaha Kecil dan Menengah (UKM). UKM mampu menyerap tenaga kerja dan menjadi sumber penghasilan tidak hanya bagi tenaga kerja namun juga pelaku usaha. Menurut Undang-undang No 20 Tahun 2008, Usaha Mikro, Kecil, dan Menengah (UMKM) merupakan kegiatan usaha yang mampu memperluas lapangan pekerjaan dan memberikan pelayanan ekonomi secara luas kepada masyarakat dan dapat berperan dalam proses pemerataan dan peningkatan pendapatan masyarakat, guna mendorong pertumbuhan ekonomi dan berperan dalam mewujudkan stabilitas nasional. Menurut Badan Pusat Statistik (2019), usaha kecil memiliki jumlah tenaga kerja 5-19 orang dan usaha menengah memiliki 20-99 orang.

Industri kecil dan menengah yang tumbuh dan berkembang di Kota Tarakan dapat dikelompokkan dalam sembilan kelompok yaitu (1) makanan, minuman, dan tembakau; (2) tekstil, barang kulit, dan alas kaki; (3) barang kayu dan hasil hutan; (4) kertas dan barang cetakan, (5) pupuk, kimia, dan barang dari karet, (6) semen dan galian non logam; (7) logam dasar, besi, dan baja; (8) alat angkut, mesin, dan peralatan; dan (9) barang lainnya. Hasil Sensus Ekonomi tahun 2016 di Kota Tarakan menurut Widiyantono (2017) menunjukkan UMKM yang bergerak pada usaha penyediaan akomodasi dan penyediaan makanan dan minuman sebesar $17,54 \%$.

Pada tahun 2018 jumlah UMKM yang terdata di Provinsi Kalimantan Utara adalah 12.089 unit usaha. Jumlah usaha kecil di Kota Tarakan tahun 2007 lebih tinggi (54 unit usaha) dibandingkan dengan industri menengah (6 unit usaha). Jumlah usaha kecil dan menengah terus meningkat di kota tersebut. Usaha kecil menjadi berjumlah 408 unit usaha pada tahun 2018 sedangkan usaha menengah berjumlah 112 unit usaha. Jumlah usaha kecil di Kota Tarakan lebih tinggi dibandingkan di Kabupaten Tana Tidung (27 buah) dan Malinau (62 buah), namun lebih rendah dibandingkan Kabupaten Bulungan (431 buah) dan Nunukan (556 buah). Sementara itu jumlah usaha menengah di Kota Tarakan lebih rendah dibandingkan dengan Kabupaten Malinau (433 buah) dan Nunukan (198 buah), tetapi lebih tinggi jika dibandingkan dengan Kabupaten Bulungan (52 buah) dan Tana Tidung (Dinas Perindustrian, Perdagangan, Koperasi, dan UMKM Provinsi Kalimantan Utara (Disperindagkop Prov Kaltara, 2018).

UKM diharapkan dapat terus meningkat jumlahnya agar dapat meningkatkan perekonomian daerah melalui peningkatan kesejahteraan pelaku usahanya. Walaupun data di atas menunjukkan bahwa jumlah UKM di Kota Tarakan terus meningkat, namun diharapkan peningkatan jumlah UKM hendaknya diiringi juga adanya pengembangan usaha. Dengan demikian diharapkan usaha kecil yang ada meningkat menjadi usaha menengah dan usaha menengah dapat meningkat menjadi usaha besar, tidak hanya stagnan pada level usaha tertentu. Jika pengembangan usaha dapat berhasil dilakukan maka akan semakin banyak lapangan kerja dan semakin besar angkatan kerja yang akan terserap. Kegiatan pengembangan UKM kelompok makanan, minuman, dan tembakau dipengaruhi oleh berbagai faktor baik faktor internal maupun faktor eksternal. Faktor-faktor internal adalah berbagai faktor yang berasal dari dalam UKM yang berperan dalam menentukan tingkat kinerja dan perkembangan UKM. Sementara itu faktor-faktor eksternal adalah berbagai faktor yang dari luar UKM atau dari lingkungan sekitar UKM yang berperan dalam perkembangan UKM.

Penelitian ini bertujuan untuk (1) Mengidentifikasi faktor-faktor internal yang berperan dalam pengembangan UKM kelompok makanan, minuman, dan tembakau; (2) Mengidentifikasi faktor-faktor eksternal yang berperan dalam pengembangan UKM kelompok makanan, minuman, dan tembakau; (3) Menentukan strategi pengembangan UKM 
kelompok makanan, minuman, dan tembakau; dan (4) Menyusun program dan kegiatan pengembangan UKM kelompok makanan, minuman, dan tembakau.

\section{METODE}

Lokasi penelitian di Kota Tarakan, Provinsi Kalimantan Timur, Indonesia. Penelitian dilaksanakan pada bulan Januari hingga Juni 2018. Penelitian ini mengumpulkan data primer dan sekunder. Data primer diperoleh dengan melakukan wawancara dengan responden. Penelitian ini menetapkan jumlah responden sebanyak 21 orang secara purposive. Responden adalah pemilik UKM yang bergerak di bidang usaha pengolahan dan pemasaran makanan, minuman, dan tembakau. Data sekunder diperoleh dari BPS dan Disperindagkop Prov Kaltara. Data dianalisis dengan menggunakan analisis Strengths, Weakness, Opportunities, and Threats (SWOT). Hal ini sejalan dengan Rangkuti (2002) yang menyatakan bahwa proses pengambilan keputusan strategis selalu berkaitan dengan pengembangan misi, tujuan, strategi, dan kebijakan perusahaan; di mana model analisis situasi yang dapat digunakan adalah analisis SWOT.

\section{HASIL DAN PEMBAHASAN}

UKM kelompok makanan, minuman, dan tembakau memiliki potensi yang besar untuk berkembang. Hasil penelitian menunjukkan bahwa pada umumnya responden (65\%) menilai bahwa UKM kelompok makanan, minuman dan tembakau memiliki faktor internal dan eksternal yang mendukung upaya untuk pengembangan usaha. Sementara itu hanya sebagian kecil responden (35\%) yang menilai masih terdapat beberapa faktor yang menghambat upaya untuk mengembangkan usaha. Hal tersebut didasarkan penilaian beberapa indikator pengembangan usaha yang telah ditetapkan.

Faktor-faktor internal yang berperan dalam pengembangan UKM kelompok makanan, minuman, dan tembakau (Tabel 1) adalah:

1. Motivasi

Motivasi kerja para pelaku UKM kelompok makanan, minuman, dan tembakau pada umumnya sangat tinggi. Responden yang memiliki motivasi kerja yang tinggi adalah mereka yang menjadikan usaha yang dikelola saat ini adalah sumber pendapatan utama serta memiliki persepsi positif terhadap perkembangan usaha (81\% responden). Motivasi kerja akan mendorong pelaku usaha untuk mengembangkan UKM yang dikelolanya. Hanya sebagian kecil responden (19\%) yang menjadikan usaha yang dikelolanya sebagai usaha sampingan.

2. Bahan baku

Sebagian besar responden (90\%) tidak memiliki persediaan bahan baku. Hal ini berarti kegiatan pembelian bahan baku dilakukan sebagian besar responden setiap hari. Beberapa jenis produk yang dihasilkan dan dipasarkan oleh UKM adalah produk makanan yang tidak tahan lama seperti tempe, tahu, mie, roti, dan kue basah. Kegiatan produksi dilakukan setiap hari memerlukan bahan baku yang kontinyu. Tidak adanya persediaan bahan baku menyebabkan UKM sangat rentan terhadap perubahan harga bahan baku di pasar serta perubahan kualitas barang yang dihasilkan karena bahan baku dapat berubah setiap hari. Hal ini dapat menyebabkan rendahnya modal usaha.

3. Tenaga kerja

Pengembangan usaha dipengaruhi besar kecilnya biaya produksi. Salah satu komponen biaya produksi adalah upah tenaga kerja. Upah bagi tenaga kerja yang terlibat pada kegiatan usaha disesuaikan dengan jenis pekerjaan, beban kerja, dan kemampuan tenaga kerja. Upah tenaga kerja pada kegiatan UKM kelompok makanan, minuman, dan tembakau bersaing dengan kegiatan UKM kelompok yang lain. Upah yang sesuai 
menyebabkan biaya produksi produk dapat bersaing dengan biaya produksi produk sejenis.

4. Modal usaha

Pembentukan modal usaha pada UKM kelompok makanan, minuman, dan tembakau relatif rendah yaitu tidak ada atau di bawah $10 \%$ dari keuntungan. Hal ini mengindikasikan bahwa keuntungan usaha sebagian besar digunakan untuk kegiatan konsumsi rumah tangga sehingga kegiatan pembentukan modal sulit dilakukan. Pembentukan modal yang rendah menghambat kegiatan ekspansi usaha yang pada akhirnya akan menurunkan daya saing UKM.

5. Keuangan

Sebagian pelaku UKM (14 responden atau 67\%) melakukan kegiatan pencatatan sedangkan sebagian lainnya tidak. Kegiatan pencatatan ada yang dilaksanakan secara berkala pada periode harian, mingguan atau bulanan. Kegiatan pencatatan akan memudahkan evaluasi usaha yang telah dijalankan. Perubahan yang cepat dapat dilakukan apabila terjadi perubahan harga faktor produksi yang mengakibatkan perubahan biaya produksi dan perubahan penerimaan akibat perubahan harga produk. Kegiatan pengelolaan keuangan belum diperhatikan secara serius oleh pelaku UKM. Perhitungan harga pokok produk hanya dilakukan oleh sebagian pelaku usaha. Kegiatan perhitungan rugi laba dan penentuan harga pokok produk pada umumnya tidak dilakukan secara rutin oleh UKM. Hal ini menyebabkan sebagian UKM mengeluarkan biaya ekonomi yang tinggi dalam kegiatan produksi barang dan jasa.

6. Teknologi produksi

Pelaku usaha memiliki kemampuan penyediaan teknologi yang sesuai dengan tuntutan kebutuhan industri. Teknologi yang tepat akan meningkatkan kualitas produk yang dihasilkan yang pada akhirnya akan meningkatkan daya saing produk-produk yang dihasilkannya. Teknologi yang digunakan saat ini dapat meningkatkan daya saing industri. Hal ini disebabkan makanan dan minuman diolah dengan menggunakan teknologi pengolahan yang tepat sehingga kendala waktu konsumsi dan risiko kerusakan dapat diminimalisasi. Jenis usaha yang dikembangkan UKM pada umumnya menghasilkan produk makanan dan minuman yang dikonsumsi masyarakat. Teknologi pengolahan bahan makanan dan minuman yang tepat akan meningkatkan kualitas makanan dan minuman yang dihasilkan.

7. Pemasaran

Penetapan harga jual merupakan kekuatan yang dimiliki pelaku industri untuk menguasai pasar serta menentukan seberapa tinggi kemampuan untuk mengembangkan usaha. Penetapan harga jual produk dilakukan berdasarkan harga pokok produksi dan kesepakatan harga antara produsen/penjual dan konsumen. Penetapan harga jual produk akan semakin mudah jika kegiatan pencatatan dilaksanakan dengan tepat. Sebagian besar pelaku UKM tidak melakukan kegiatan promosi. Kegiatan pengemasan hanya dilakukan sesuai kebutuhan saja, bahkan ada yang tidak melakukan pengemasan produk yang dihasilkan. Hal ini menyebabkan harga jual produk menjadi rendah, kualitas produk tidak dilindungi, dan resiko kerusakan produk menjadi semakin besar. Cara penjualan dilakukan oleh sebagian responden masih pasif di mana pelaku industri menunggu konsumen. Cara pemasaran yang pasif menyebabkan sempitnya wilayah pemasaran dan rendahnya jumlah konsumen yang dapat dilayani. Pemasaran produk makanan dan minuman menjangkau wilayah dalam dan di luar Kota Tarakan.

8. Iklim usaha

Produk yang dihasilkan/dipasarkan oleh UKM memiliki kemampuan bersaing dengan produk sejenis dari luar maupun dari dalam Kota Tarakan. Kemampuan bersaing menunjukkan bahwa produk yang dihasilkan memiliki kualitas yang setara atau lebih 
tinggi dibandingkan produk pesaing. Hal ini diindikasikan bahwa tingkat permintaan akan produk UKM masih tetap tinggi dan usaha masih berkembang.

9. Pembinaan

Kegiatan pembinaan dari pemerintah sangat membantu meningkatkan kemampuan untuk pengembangan usaha oleh UKM. Pelaku industri pada umumnya merasakan manfaat pembinaan yang telah dilakukan pemerintah. UKM akan semakin meningkat jika kegiatan pembinaan dapat dilakukan secara berkala.

Tabel 1. Penilaian faktor internal.

\begin{tabular}{|c|c|c|c|c|c|c|}
\hline No. & Kategori & Indikator & $\begin{array}{c}\text { Tinggi } \\
\text { (responden) }\end{array}$ & $\begin{array}{c}\text { Rendah } \\
\text { (responden) }\end{array}$ & $\begin{array}{c}\text { Tinggi } \\
(\%)\end{array}$ & $\begin{array}{c}\text { Rendah } \\
(\%)\end{array}$ \\
\hline \multicolumn{7}{|c|}{ Faktor Internal: Kekuatan } \\
\hline 1 & Motivasi & Motivasi kerja. & 17 & 4 & 81 & 19 \\
\hline 2 & Bahan baku & Persediaan bahan baku. & 2 & 19 & 10 & 90 \\
\hline 3 & Modal usaha & Pembentukan modal. & 7 & 14 & 33 & 67 \\
\hline 4 & Keuangan & Administrasi & 14 & 7 & 67 & 33 \\
\hline 5 & & Perhitungan rugi laba. & 9 & 12 & 43 & 57 \\
\hline \multirow[t]{2}{*}{6} & & Perhitungan harga pokok & & & & \\
\hline & & produk. & 10 & 11 & 48 & 52 \\
\hline 7 & Pemasaran & Wilayah pemasaran. & 20 & 1 & 95 & 5 \\
\hline 8 & Iklim usaha & $\begin{array}{l}\text { Daya saing dengan produk } \\
\text { sejenis dari luar kota. }\end{array}$ & 16 & 5 & 76 & 24 \\
\hline 9 & & $\begin{array}{l}\text { Daya saing dengan produk } \\
\text { sejenis dari dalam kota. }\end{array}$ & 16 & 5 & 76 & 24 \\
\hline 10 & Pembinaan & $\begin{array}{l}\text { Manfaat kegiatan } \\
\text { pembinaan bagi } \\
\text { kemajuan usaha. }\end{array}$ & 12 & 9 & 57 & 43 \\
\hline \multicolumn{7}{|c|}{ Faktor Internal: Kelemahan } \\
\hline 1 & Tenaga kerja & Upah/gaji tenaga kerja. & 17 & 4 & 81 & 19 \\
\hline \multirow[t]{2}{*}{2} & Teknologi & Kemampuan & & & & \\
\hline & & memanfaatkan teknologi. & 15 & 6 & 71 & 29 \\
\hline 3 & & Ketepatan teknologi. & 18 & 3 & 86 & 14 \\
\hline 4 & Pemasaran & $\begin{array}{l}\text { Penetapan harga jual } \\
\text { produk. }\end{array}$ & 16 & 5 & 76 & 24 \\
\hline 5 & & Promosi. & 2 & 19 & 10 & 90 \\
\hline 6 & & Pengemasan & 2 & 19 & 10 & 90 \\
\hline 7 & & Cara penjualan. & 12 & 9 & 57 & 43 \\
\hline
\end{tabular}

Sumber: Data primer (2018).

Faktor-faktor eksternal yang berperan dalam kemampuan pengembangan UKM kelompok makanan, minuman, dan tembakau (Tabel 2) adalah:

1. Bahan baku

Bahan baku yang digunakan UKM kelompok makanan, minuman, dan tembakau untuk proses produksi barang dan jasa selalu tersedia dalam jumlah cukup di Kota Tarakan. Bahan baku UKM umumnya berasal dari produksi pertanian. Produksi tanaman pangan, produk ternak, dan perikanan menunjang pengembangan UKM. Ketersediaan bahan baku terjamin karena bahan baku sebagian besar berasal dari wilayah Kota Tarakan dan sebagian kecil dari luar wilayah Kota Tarakan. Tingkat ketergantungan akan bahan baku impor relatif rendah. Kualitas bahan baku relatif tinggi serta harga yang murah menjadi UKM ini memiliki potensi untuk berkembang.

Kemampuan pengusaha dalam menyediakan bahan baku utama antara lain tepung terigu, biji kopi, dan ikan segar bagi UKM/industri masih rendah dan terbatas. Persediaan bahan baku yang dimiliki pelaku usaha untuk kegiatan produksi masih rendah. Beberapa jenis bahan baku sebagian dapat disimpan tetapi hanya dalam jangka waktu terbatas 
karena waktu penyimpanan akan mempengaruhi kualitas bahan baku seperti tepung terigu. Bahan baku seperti daging segar dan biji kopi dari konsumen serta ikan segar langsung diolah sehingga pengusaha UKM memang tidak perlu memiliki persediaan bahan baku dalam jumlah yang besar.

2. Tenaga kerja

Tenaga kerja yang diperlukan untuk pengembangan UKM tersedia dalam jumlah yang cukup besar di masyarakat. Kualitas tenaga kerja pada umumnya sesuai dengan kebutuhan industri. Tenaga kerja antara lain dihasilkan dari lembaga pendidikan yang ada di wilayah Kota Tarakan. Ketersediaan dan kualitas tenaga kerja adalah faktor eksternal yang mempengaruhi pengembangan UKM. Kegiatan produksi untuk menghasilkan produk dengan kuantitas dan kualitas yang baik tidak dapat berlangsung jika tidak terdapat tenaga kerja sebagai pelaku UKM.

3. Modal usaha

Modal yang dibutuhkan untuk usaha sebagian berasal dari modal sendiri atau pinjaman dari lembaga keuangan atau kerabat. Pada umumnya responden mengalami kesulitan untuk mengakses permodalan. Modal merupakan faktor produksi yang sangat diperlukan untuk kegiatan produksi sehingga jumlah modal yang dimiliki akan sangat menentukan daya saing industri. Kegiatan pengembangan usaha hanya dapat dilakukan jika modal mencukupi. Tingkat investasi pada suatu daerah menentukan perkembangan ekonomi daerah (Karmini, 2014).

Keterbatasan modal usaha untuk kegiatan produksi barang dan jasa. Kondisi yang demikian disebabkan:

a. Pelaku UKM mengalami kesulitan mengakses permodalan dari lembaga keuangan yang ada di sekitar UKM disebabkan informasi tentang modal usaha yang masih terbatas dan adanya kemampuan memenuhi modal usaha dari milik sendiri.

b. Kemampuan pembentukan modal dari keuntungan usaha sangat rendah. Tingkat keuntungan usaha masih lebih rendah dibandingkan tingkat kebutuhan hidup pelaku UKM sehingga kemampuan pembentukan modal di bawah $10 \%$.

4. Teknologi produksi

Alat/teknologi yang digunakan untuk kegiatan produksi diperoleh melalui penjualan sarana produksi. Alat/teknologi untuk kegiatan produksi UKM kelompok makanan, minuman, dan tembakau tersedia di pasar. Jenis usaha yang dikembangkan oleh UKM pada umumnya adalah industri kecil di mana teknologi yang digunakan umumnya masih sederhana.

5. Pemasaran

Peluang pasar bagi produk UKM dinilai sangat atau cukup besar oleh responden. Prospek usaha UKM kelompok makanan, minuman, dan tembakau cerah. Peluang pasar yang tinggi menyebabkan UKM masih memiliki peluang untuk dikembangkan. Peluang pasar ini tetap tinggi walaupun terdapat produk bahan makanan yang berasal dari luar wilayah Tarakan. Pengembangan pasar dapat dilakukan dengan cara perluasan wilayah pemasaran, pembangunan industri pengolahan hasil pertanian, dan diversifikasi produk yang dihasilkan produsen (Karmini, 2018).

6. Iklim usaha

Faktor eksternal yang mempengaruhi pengembangan UKM adalah adanya produk dari para pesaing. Pada umumnya produk yang dihasilkan oleh setiap jenis usaha UKM kelompok ini juga dihasilkan oleh pesaing bisnis yang lain. Hal ini menyebabkan tingkat kompetisi antara produk yang dihasilkan menjadi sangat tinggi. Oleh sebab itu pelaku industri harus meningkatkan dan mempertahankan kualitas produk yang dihasilkan agar mampu bersaing dengan produk yang dihasilkan pesaing. 
7. Pembinaan

Kegiatan pembinaan yang dilakukan pemerintah menunjang daya saing UKM. Beberapa responden (19 orang) pernah mendapatkan pembinaan dari pemerintah. Kegiatan pembinaan yang dilakukan dinilai beragam ada yang menilai sangat, cukup atau kurang intensif. Menurut Nugroho dkk. (2019), sudah selayaknya UMKM mendapat dukungan terutama dari pemerintah dan dari sektor-sektor lain karena UMKM merupakan salah satu penopang ekonomi negara.

Tabel 2. Penilaian faktor eksternal.

\begin{tabular}{|c|c|c|c|c|c|c|}
\hline No. & Kategori & Indikator & $\begin{array}{c}\text { Tinggi } \\
\text { (responden) }\end{array}$ & $\begin{array}{c}\text { Rendah } \\
\text { (responden) }\end{array}$ & $\begin{array}{c}\text { Tinggi } \\
(\%)\end{array}$ & $\begin{array}{c}\text { Rendah } \\
(\%)\end{array}$ \\
\hline \multicolumn{7}{|c|}{ Faktor Eksternal: Peluang } \\
\hline 1 & Bahan baku & Asal bahan baku. & 12 & 9 & 57 & 43 \\
\hline 2 & Modal usaha & Sumber modal. & 21 & 0 & 100 & 0 \\
\hline 3 & & $\begin{array}{l}\text { Akses terhadap sumber } \\
\text { modal. }\end{array}$ & 10 & 11 & 48 & 52 \\
\hline 4 & Teknologi & Ketersediaan teknologi. & 14 & 7 & 67 & 33 \\
\hline 5 & Pemasaran & $\begin{array}{l}\text { Peluang pasar produk } \\
\text { industri. }\end{array}$ & 16 & 5 & 76 & 24 \\
\hline 6 & Pembinaan & Kegiatan pembinaan. & 11 & 10 & 52 & 48 \\
\hline \multicolumn{7}{|c|}{ Faktor Eksternal: Ancaman } \\
\hline 1 & Bahan baku & Ketersediaan bahan baku. & 14 & 7 & 67 & 33 \\
\hline 2 & & Kualitas bahan baku. & 21 & 0 & 100 & 0 \\
\hline 3 & & Harga bahan baku & 15 & 6 & 71 & 29 \\
\hline 4 & Tenaga kerja & Ketersediaan tenaga kerja. & 18 & 3 & 86 & 14 \\
\hline 5 & & Kualitas tenaga kerja. & 20 & 1 & 95 & 5 \\
\hline 6 & Iklim usaha & Produk sejenis. & 21 & 0 & 100 & 0 \\
\hline
\end{tabular}

Sumber: Data primer (2018).

Hasil studi Karmini (2019) menunjukkan faktor internal memiliki nilai skor kekuatan sebesar 2,78 poin sedangkan nilai skor kelemahan sebesar 1,86 poin atau terdapat selisih 0,92 poin. Faktor eksternal memiliki nilai skor peluang sebesar 2,61 poin sedangkan nilai skor ancaman sebesar 0,48 poin atau terdapat selisih 2,13 poin. Strategi pengembangan UKM kelompok makanan, minuman, dan tembakau adalah agresif yaitu:

1. Peningkatan kemampuan UKM dalam bidang menyediakan bahan baku. Strategi ini dipilih agar tingkat persediaan bahan baku UKM dapat meningkat sehingga kegiatan produksi terjamin.

2. Peningkatan modal usaha yang dimiliki oleh pengusaha dan pengelola UKM. Strategi ini ditempuh agar pengusaha UKM meningkatkan daya beli bahan baku, peningkatan daya beli faktor produksi seperti tenaga kerja, alat, mesin, dan teknologi yang dibutuhkan kegiatan produksi.

3. Peningkatan kemampuan pengusaha dalam bidang manajemen produksi dan keuangan. Strategi ini bertujuan agar pelaku UKM mampu meningkatkan akurasi perhitungan harga pokok produksi.

Penelitian ini merumuskan beberapa program kerja untuk mengembangkan UKM kelompok makanan, minuman, dan tembakau serta kegiatan yang dapat dilakukan untuk mengimplementasikan program kerja tersebut. Program dan kegiatan pengembangan Usaha Kecil dan Menengah (UKM) kelompok makanan, minuman, dan tembakau antara lain:

1. Program identifikasi dan pengembangan potensi daerah. Kegiatan-kegiatan pokok yang dapat dilakukan antara lain: 
a. Penelitian tentang peluang pemanfaatan sumberdaya lokal untuk bahan baku UKM serta pengembangan dan penyediaan teknologi penyimpanan bahan baku.

b. Pengembangan bahan baku terbarukan.

c. Peningkatan kemampuan pelaku usaha dalam pemanfaatan teknologi untuk penyimpanan bahan baku misalnya melalui penyuluhan dan berbagai bentuk diseminasi pengetahuan lainnya. Keberhasilan kegiatan ini adalah pengetahuan pelaku UKM bertambah.

d. Perluasan pasar produk UKM baik melalui daring maupun luring. Menurut Nugroho dkk. (2019) diperlukan adanya strategi percepatan adopsi penggunaan informasi dan teknologi bagi usaha mikro terutama media daring yang dapat ditempuh dengan cara antara lain penyediaan infrastruktur teknologi dan informasi yang merata, penyediaan tenaga ahli di bidang teknologi informasi yang kompeten, pemberian bantuan teknologi informasi kepada usaha mikro, dan adanya sosialisasi manfaat informasi dan teknologi dalam pengembangan usaha mikro.

2. Program penguatan kemampuan ekonomi UKM. Kegiatan-kegiatan pokok yang dilakukan adalah:

a. Pembentukan lembaga keuangan kecil oleh kelompok industri sejenis untuk meningkatkan kemandirian UKM.

b. Pemberdayaan koperasi dan lembaga keuangan yang ada di sekitar UKM melalui kegiatan pendampingan agar koperasi dan lembaga keuangan beraktivitas optimal.

c. Peningkatan investasi pada UKM. Indikator keberhasilan kegiatan adalah jumlah investor meningkat.

d. Penyediaan modal usaha dan peningkatan aksesibilitas terhadap oleh lembaga keuangan dan Pemerintah Daerah (Pemda). Indikator keberhasilan kegiatan adalah jumlah pelaku UKM yang mendapatkan modal usaha meningkat.

e. Menfasilitasi kegiatan pemberian kredit bagi UKM oleh lembaga keuangan oleh Pemda dan lembaga keuangan agar semakin besar jumlah kredit yang dapat tersalurkan ke UKM.

f. Pembentukan hubungan kemitraan antara pelaku usaha dan lembaga keuangan.

3. Program peningkatan jumlah wirausahawan muda. Kegiatan-kegiatan pokok yang dapat dilakukan antara lain:

a. Pengkajian kegiatan produksi makanan dan minuman dengan tujuan agar kegiatan produksi dapat terinventarisasi dan terpublikasikan dengan baik sehingga meningkatkan minat berwirausaha.

b. Peningkatan aksesibilitas pelaku IKM terhadap bimbingan teknis tentang kegiatan manajemen produksi dan keuangan agar kemampuan dan keterampilan usaha/skill dari para pelaku usaha meningkat.

c. Mencetak wirausahawan muda melalui kegiatan pelatihan dan pendampingan usaha.

d. Pembangunan, perbaikan, dan pemeliharaan sarana dan prasarana pendidikan kewirausahawan seperti balai pelatihan, instruktur, program pendidikan, dana, beasiswa dan lain-lain sehingga sarana dan prasarana pendidikan tersedia dan terpelihara.

\section{KESIMPULAN}

Faktor-faktor internal dan eksternal yang berperan dalam pengembangan UKM kelompok makanan, minuman, dan tembakau antara lain motivasi, bahan baku, tenaga kerja, modal usaha, keuangan, teknologi produksi, pemasaran, iklim usaha, dan pembinaan. 


\section{REKOMENDASI}

Strategi pengembangan UKM kelompok makanan, minuman, dan tembakau adalah agresif dan dapat dilakukan dengan cara peningkatan kemampuan UKM dalam menyediakan bahan baku dan peningkatan modal usaha serta manajemen produksi dan keuangan. Program dan kegiatan pengembangan UKM kelompok makanan, minuman, dan tembakau antara lain program identifikasi dan pengembangan potensi daerah yang terdiri dari 4 kegiatan pokok, program penguatan kemampuan ekonomi UKM yang dijabarkan dalam 6 kegiatan pokok, dan program peningkatan jumlah wirausahawan muda yang meliputi 4 kegiatan pokok.

\section{DAFTAR PUSTAKA}

Badan Pusat Statistik Indonesia. (2019). Industri Pengolahan. https://www.bps.go.id/subject/170/industri-mikro-dan-kecil.html. Diakses tanggal $21 \mathrm{Juli}$ 2019.

Dinas Perindustrian, Perdagangan, Koperasi, dan UKM Provinsi Kalimantan Utara (Disperindagkop Prov Kaltara). (2018). Pelaksanaan Pembangunan Bidang Koperasi dan UKM. Rapat Koordinasi Nasional Bidang UMKM Tahun 2018. Disperindagkop Prov Kaltara, Nunukan.

Karmini. (2014). Analisis Investasi Pada Kegiatan Pertanian Tanaman Pangan dan Hortikultura di Kabupaten Kutai Kartanegara. Riset Kaltim 2(4): 13-27.

Karmini. (2018). Zonasi Wilayah Pengembangan Sektor Pertanian, Kehutanan, dan Perikanan di Kabupaten Kutai Barat. Agrifor XVII(2): 305-314.

Karmini. (2019). Strategi Pengembangan Usaha Kecil dan Menengah Kelompok Makanan, Minuman, dan Tembakau di Kota Tarakan. Prosiding Seminar Nasional Pertanian 2019. Tantangan dan Peluang Menuju Pertanian Berkelanjutan. Fakultas Pertanian, Universitas Mulawarman. Balikpapan, 7 Agustus 2019. 242-248

Nugroho, B.A., Budiman, P.W., dan Wahyuningsih, N. (2019). Analisis Persepsi Usaha Mikro Terhadap Pemanfaatan Media Daring di Kota Samarinda. Riset Pembangunan 1(2): 79-89.

Rangkuti, F. (2002). Analisis SWOT Teknik Membedah Kasus Bisnis. Reorientasi Konsep Perencanaan Strategis untuk menghadapi Abad 21. Jakarta: Gramedia Pustaka Utama.

Widiyantono. (2017). Raksasa Tidur di Kaltara itu Bernama UMK. https://kaltim.tribunnews.com/2017/07/05/raksasa-tidur-dikaltara-itu-bernama-umk.

Diakses tanggal 20 Juli 2019. 